\title{
Aspiration Avoiding Tracheostomy in Neonatal Cystic Oral Lesion
}

\author{
Yenidoğan Kistik Oral Lezyonunda Trakeostomiden Kaçınma \\ Aspirasyonu
}

\author{
Mohd Shaiful Nizam Mamat NASIR $\odot$, Muhammad Nuaim ISHAK $\bullet$, Farah Hanan ABD WAHID $\odot$, \\ Jawaad Ahmed ASIF $\odot$, Irfan MOHAMAD $\odot$
}

Ethics Committee Aproval: Not Applicable.

Confillict of Interest: The authors declare that they have no conflict of interest.

Funding: None.

Informed Concent: Informed consent was taken.
Cite as: Nasir MSM, Ishak MN, Wahid FHA, Asif JA, Mohamad I. Aspiration avoiding tracheostomy in neonatal cystic oral lesion. Medeniyet Med J. 2019;34:400-3.

\begin{abstract}
Oral cyst is uncommon in the neonatal period. Depending on the size and site of occurrence, its symptoms may vary. If not diagnosed and managed expeditiously, these oral cysts may cause significant and potentially fatal morbidity and mortality. We report a successfully managed case of oral cyst in neonate that presented with huge tongue at birth and complaints of impending airway obstruction. She was referred for tracheostomy as intubation was impossible. We attempted needle aspiration and the airway successfully relieved without the need for tracheostomy.
\end{abstract}

Keywords: Cyst, tongue, oral cavity, neonate, tracheostomy

öz

Yenidoğan döneminde oral kist nadirdir. Büyüklüğüne ve oluşum yerine bağlı olarak değisşik belirtiler verebilir. Hızla teşhis edilip yönetilemezse, ölümcül olabilecek önemli morbidite ve mortaliteye neden olabilir. Bu olgu sunumunda doğumda mevcut büyük dil kitlesi olan ve hava yolu tıkanıklığı şikayeti ile gelen ve başarılı bir şekilde yönetilen bir yenidoğan oral kist vakasını bildiriyoruz. Entübasyon mümkün olmadığı için trakeostomiye sevk edilen hastada iğne ile aspire etmeyi denedik. Solunum yolu trakeostomiye gerek kalmadan başarıyla rahatladı.

Anahtar kelimeler: Kist, dil, ağız boşluğu, yenidoğan, trakeostomi
Received: 14 November 2019

Accepted: 04 September 2019 Online First: 26 December 2019

\section{Corresponding Author:} Irfan Mohamad,

ORCID: 0000-0001-8572-0514 Department of OtorhinolaryngologyHead \& Neck Surgery, School of Medical Sciences, Universiti Sains Malaysia Health Campus, 16150 Kota Bharu, Kelantan, Malaysia irfankb@usm.my

M.S.N.M. Nasir ORCID: 0000-0001-5611-7716 M.N. Ishak ORCID: 0000-0002-9511-4531 Universiti Sains Malaysia Health Campus, School of Medical Sciences, Department of Otorhinolaryngology-Head \& Neck Surgery, Kelantan, Malaysia

F.H.A. Wahid ORCID: 0000-0002-4779-0594 J.A. Asif ORCID: 0000-0002-1785-6126 Universiti Sains Malaysia Health Campus, School of Dental Sciences, Oromaxillofacial Unit, Kelantan, Malaysia 


\section{INTRODUCTION}

Cystic lesions in the oral cavity rarely occur in the neonates. The incidence estimated as 1.82 per 100000 live births in an oriental population ${ }^{1}$. The differential diagnoses include cystic hygroma, dermoid and epidermoid cyst, ranula, lingual thyroid, lymphoepithelial cyst and teratoma. Small cyst is usually asymptomatic, but a large-sized cyst can cause respiratory and feeding difficulties due to obstruction ${ }^{2}$. Tracheostomy may be warranted as intubation may also be difficult to apply.

\section{CASE SUMMARY}

A newborn girl was referred to Oral Maxillofacial (OMF) team at two hours of life for airway assessment after a huge intraoral mass was noted immediately after birth. The baby was born at term via spontaneous vaginal delivery with a good Apgar score. The mother was a 29-year-old gravida 2 , para 1 with gestational diabetes mellitus on diet control. Serial obstetric ultrasonographic examinations revealed normal fetal development. Upon delivery, the baby was noted to have a huge intraoral mass and was immediately shifted to a neonatal intensive care unit (NICU). Otherwise, she had not symptoms of shortness of breath, noisy breathing and cyanosis.

On physical examination, there were no syndromic features and the baby was comfortable on nasal cannula with delivery of oxygen at a rate of 2 litres per minute. She had a good cry. Any evidence of tachypnea and stridor was not detected. Examination of oral cavity, revealed a mass occupying the ventral surface of the tongue measuring about $3 \mathrm{~cm} \times 3 \mathrm{~cm}$, pushing the tongue superoposteriorly (Figure 1). It was pale in colour with a smooth surface and cystic consistency. Otherwise, anterior rhinoscopy revealed normal finding with good fogging bilaterally on cold spatula test.

Otorhinolaryngologist was consulted for the need of emergency tracheostomy in anticipation of the infant progressing into respiratory distress with increased chances of endotracheal intubation. We

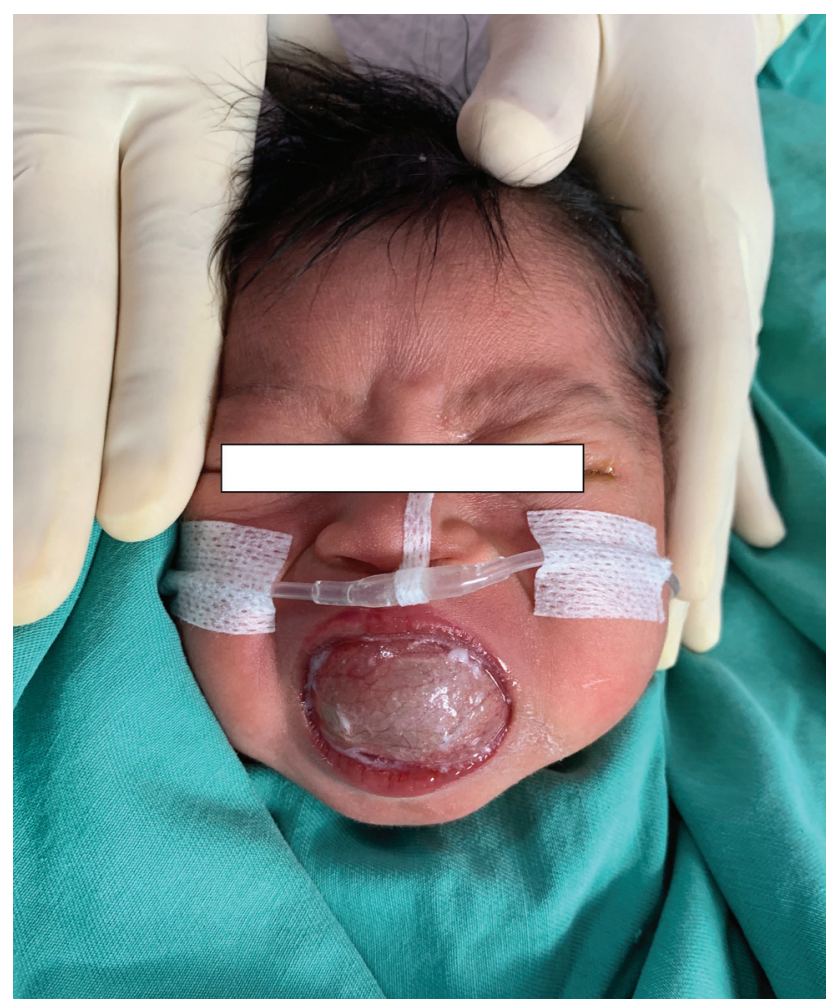

Figure 1. Mass at the ventral surface of the tongue occluding the whole oral cavity.

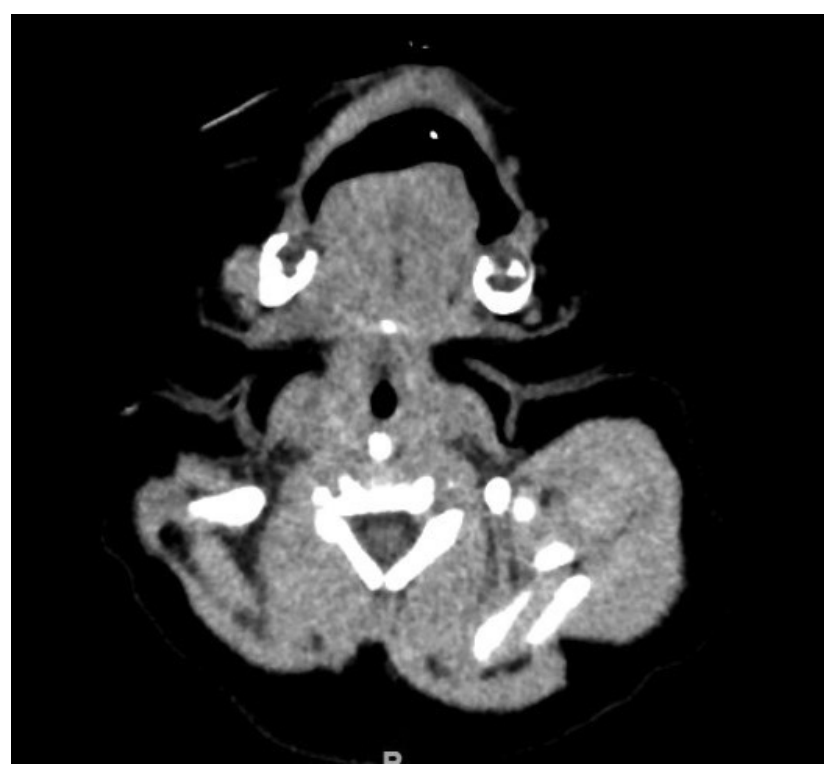

Figure 2. CT neck (axial) noted tongue is bulky and enhanced. There is ill defined area at anteroinferior part of the tongue. 
discussed with the managing OMF team the option of aspiration, once the vascular origin lesion has been ruled out. Computed tomography (CT) scan was arranged within 24 hours post-delivery, that revealed an area of fluid density at anteroinferior part of the tongue (Figure 2), without any evidence of airway obstruction and a vascular lesion on CT. Aspiration of the cyst using a 22 gauge needle drained $14 \mathrm{cc}$ of thick frothy fluid which was sent for cytology. With single aspiration procedure, the cystic mass subsided after aspiration with resultant adequate intraoral airway passage which aided in perfect lip seal facilitating suckling (Figure 3).

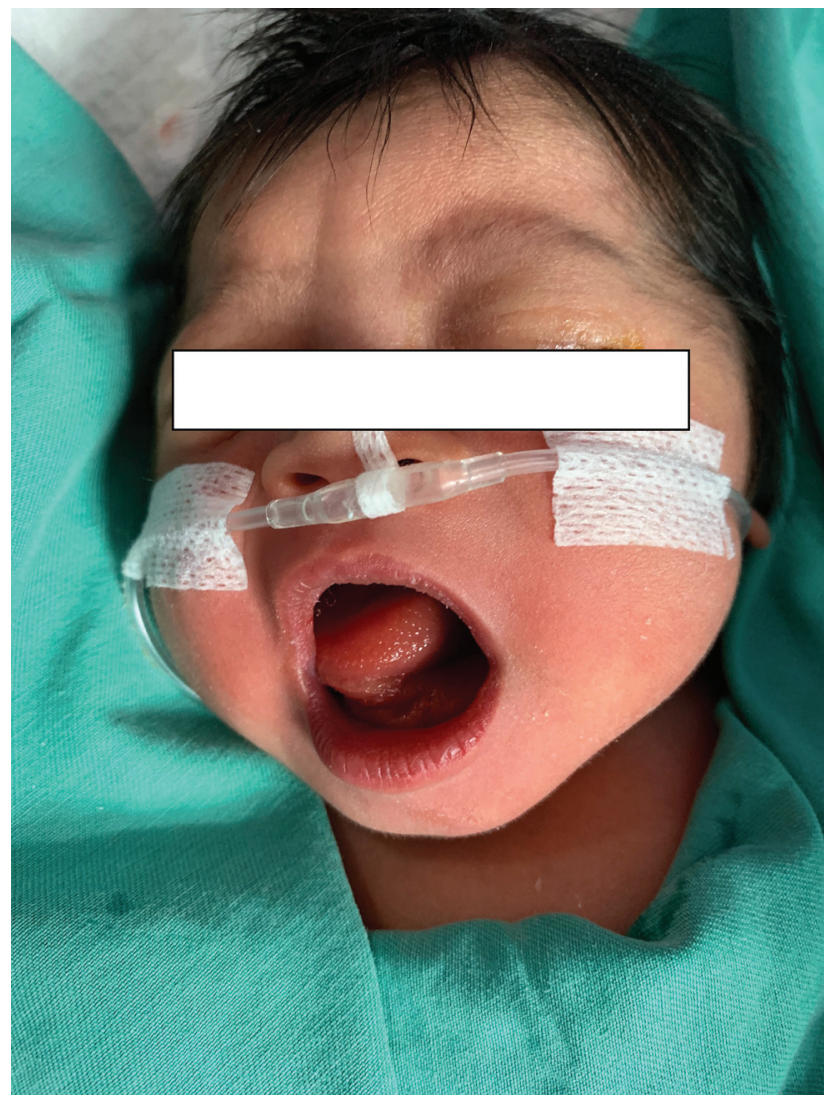

Figure 3. Post aspiration enabled the newborn to obtain wide mouth opening and perfect lip seal for sucking.

However, after 2 weeks following aspiration, the fluid refilled the comparatively smaller cavity without causing respiratory distress, then re-aspiration was performed and $7 \mathrm{cc}$ of thick frothy fluid was obtained. Cytology result suggested the presence of a benign lingual cyst lined with squamous epithelium without detected malignant cells.

After the aspiration the swelling resolved. Patient was monitored for $\mathbf{4 8}$ hours and then discharged with follow-up appointment. However, during two weeks of outpatient follow up, the cyst recurred again without any sign of respiratory distress. Forty days after her birth, the patient successfully underwent cyst enucleation with removal of left sublingual gland.

\section{DISCUSSION}

Cysts and tumours of the tongue are uncommon in neonate population. Midline cysts at the base of the tongue are rarely seen and often undertreated, frequently leading to mortality ${ }^{3}$. Physiologic hypertrophied lingual tonsil, macroglossia, neoplasms such as dermoid cyst, teratoma, lymphangioma, or hemangioma are also considered in the differential diagnosis of tongue base masses in neonates ${ }^{4}$. Foregut duplication cyst of the head and neck, although very rarely seen should be also included in the differential diagnosis of cystic head and neck lesions because they most frequently occur in the oral cavity ${ }^{5}$.

Most affected patient will manifest their symptoms during the first week of life ${ }^{6}$. Depending on its size and location of the mass, clinical manifestations consist of various degrees of upper airway obstruction such as inspiratory stridor, chest retraction, cyanosis, and feeding ${ }^{6}$. The neonate being reported showed no evidence of respiratory distress although the sublingual cyst occupied the whole anterior oral cavity. In some cases, the presence of huge oral or neck mass in foetus can be detected during antenatal scan and potential airway obstruction should be anticipated in these cases. The ex-utero intrapartum treatment (EXIT) procedure is used to secure the foetal airway during delivery so as to improve the chances of survival of the foetus. The principle of the EXIT is to maintain uteroplacental circulation while a paedi- 
atric otorhinolaryngologist evaluates and secure the airways, then proceed with surgical removal of the masses if needed ${ }^{7}$.

Clinical bedside examination by manual palpation of the oral cavity should be gently done as it can induce laryngospasm and rupture of the cyst. Flexible nasopharyngeal laryngoscopy can be performed to analyse the extension of the mass. If the mass is not localized or does not prove to be cystic, further evaluation CT should be performed to narrow the spectrum of differential diagnosis including thyroglossal duct, lymphangioma, hemangioma, dermoid cyst or lipoma ${ }^{7}$. Although CT results can be immensely valuable in diagnosis of such lesions in neonates, risk of radiation exposure should be considered and avoided if not deemed to be necessary ${ }^{7}$. Other imaging options such as lateral neck radiograph or ultrasonography can be considered if the lesion is not life threatening.

Radiological imaging of postnatal cysts is necessary for a definitive diagnosis. Treatment including aspiration, intraoral excision or marsupialization has become the standard therapy by most otorhinolaryngologists and maxillofacial surgeons ${ }^{4}$. Most patients with tongue base cysts show improved symptoms after surgical resection ${ }^{8}$.

Early surgical intervention may be required in case of worsening airway obstruction. As we have demonstrated in this case, aspiration of the cyst showed immediate decompression with instant relief, but it is often associated with recurrence?. For definitive treatment surgical management such as enucleation excision or marsupialization via trans-oral approach is required ${ }^{9}$. Tracheostomy in paediatric patients, especially in neonates is very challenging. It is not only because of the limited anatomical exposure during tracheosto- my, but its most challenging part is postoperative care that needs very special and close monitoring to avoid complication such as dislodge tracheostomy tube.

\section{CONCLUSION}

Successful management of the presented case emphasizes the need of early diagnosis and prompt surgical intervention. We also emphasize the inclusion of aspiration as one of the modalities in treatment options for optimal management of neonatal oral cysts thus avoiding the need for invasive surgical procedure such as tracheostomy.

\section{REFERENCES}

1. Ahrens B, Lammert I, Schmitt M, Wahn U, Paul K, Niggemann B. Life-threatening vallecular cyst in a 3-month-old infant: case report and literature review. Clin Pediatr (Phila). 2004;43:287-90. [CrossRef]

2. Tucker R, Maddalozzo J, Chou P. Sublingual enteric duplication cyst. Arch Pathol Lab Med. 2000;124:614-5.

3. Yang MA, Kang MJ, Hong J, et al. A case of congenital vallecular cyst associated with gastroesophageal reflux presenting with stridor, feeding cyanosis, and failure to thrive. Korean Journal of Pediatrics. 2008;51:775-779. [CrossRef]

4. Wong $\mathrm{KS}$, Huang $\mathrm{YH}$, Wu CT. A vanishing tongue-base cyst. Turk J Pediatr. 2007;49:451-2.

5. Kieran SM, Robson CD, Nosé V, Rahbar R. Foregut duplication cysts in the head and neck: presentation, diagnosis, and management. Arch Otolaryngol Head Neck Surg. 2010;136:778-82. [CrossRef]

6. Sands NB, Anand SM, Manoukian JJ. Series of congenital vallecular cysts: a rare yet potentially fatal cause of upper airway obstruction and failure to thrive in the newborn. J Otolaryngol Head Neck Surg. 2009;38:6-10.

7. Pucher B, Szydlowski J, Jonczyk-Potoczna K, Sroczynski J. The EXIT (ex-utero intrapartum treatment) procedure - from the paediatric ENT perspective. Acta Otorhinolaryngol Ital. 2018;38:480-4. [CrossRef]

8. LaBagnara J Jr. Cysts of the base of the tongue in infants: an unusual cause of neonatal airway obstruction. Otolaryngol Head Neck Surg. 1989;101:108-11. [CrossRef]

9. Jing SS, Alberry MS, Smith RP, Clibbon JJ. A rare report of foetal lingual cyst excised with harmonic scalpel. J Plast Reconstr Aesthet Surg. 2013;66:1770-2. [CrossRef] 